pathology, just as it is also with bacteriology, it is nevertheless necessary to keep it absolutely distinct.

Before sitting down, I should like to publicly express my hearty thanks to Dr. Howard and to the members of the Bureau and also to entomologists in the United States-for their hearty coöperation with us in our work in Canada. I realize more than anyone else the necessity of our work being international in scope and character. The international boundary is not recognized by our governments in a military manner and as insects do not recognize such political frontiers, we shall succeed best in our efforts by the closest coöperation over the whole range covered by the insects we may be endeavoring to control.

Mr. F. P. FelT: It is unnecessary to discuss Dr. Howard's paper, because he has given us a most admirable summary; but I think, speaking for myself and probably for other members of the Association, that we all heartily indorse Dr. Howard's position.

President H. T. Fernald: I have been very much interested in Dr. Howard's remarks and heartily agree with him on every point which he has made-in fact, the paper was so conclusive that I questioned in my own mind if there would be the possibility of much discussion on lines where we were all certainly so much in hearty agreement with the positions he took.

\title{
Report of the Section of Apiary Inspection
}

The third annual meeting of the Section of Apiary Inspection was held in Philadelphia, Monday evening, December 28, 1914. Inspec-. tors were present from ten different states. Reports of progress being made in apiary inspection work were given by all inspectors present. It was reported that efforts are now being made by several states to have a new apiary inspection law passed. Two states reported failure on the part of their legislators to make appropriation for apiary inspection but stated that the mistake would probably result in larger appropriations at the next session. Reports from other states indicate increasing appropriations for this kind of work.

Dr. E. F. Phillips reported that he had on hand an unexpended balance of $\$ 14.25$, left from membership dues received from members of the Association of Official Apiary Inspectors of the United States and Canada which was organized December, 1911, at Washington. After this association affiliated with the Association of Economic Entomologists as the Section of Apiary Inspection, it was impossible for eleven of these members to become members of the section because they were not entomologists. Dr. Phillips proposed that membership dues be returned to these eleven men and that the balance of $\$ 3.25$ 
be turned over to the Secretary of the Association of Economic Entomologists. The Section expressed its approval of this plan.

Dr. E. F. Phillips, of Washington, D. C., was elected Chairman and N. E. Shaw, Columbus, Secretary, for the coming year. These selections were recommended to the nominating committee of the Association of Economic Entomologists.

N. E. Shaw.

\section{ADDRESS OF THE CHAIRMAN}

By Wilmon Newelt, College Station, Texas

The Section of Apiary Inspection is a comparatively recent development in the Association of Economic Entomologists. This body was formally organized in Washington, D. C., in December, 1911, under the name of the "Association of Official Apiary Inspectors of the United States and Canada." A year later, at the Cleveland meeting, it affiliated with the Association of Economic Entomologists and received the rank of a section. A short but interesting program of the section was held at the Atlanta meeting a year ago.

The work of the economic entomologist is mainly one of conservation. It is his province to provide methods of protecting crops, fruits, etc., either in the course of their production or after they have been harvested. The conviction that this constituted the sole field of the economic entomologist was so firmly fixed that even the entomologists themselves did not regard the study of wealth-producing insects, such as the honey-bee, as a legitimate part of their work.

However, it must be conceded that the study of beneficial insects of every kind constitutes economic entomological work just as surely as does the study of injurious forms.

It was but appropriate, then, that entomologists, though somewhat tardily, should turn their attention to the development of the beekeeping industry and to the problems connected therewith. Six Experiment Stations, Minnesota, Iowa, Massachusetts, Oklahoma, Texas, and Ontario, Can., now operate experimental apiaries for the development of better methods of beekeeping and the Bureau of Entomology at Washington has done much in recent years to bring the beekeeping industry into the prominence which its importance merits.

The most important phase of this work has been the protection of bees against infectious and contagious diseases and many states now maintain, through their state entomological departments, an efficient apiary inspection system, not unlike the older system of nursery and orchard inspection. In states where this work has been in other hands 